\title{
Exploration and Research on the Combination of "One Village, One Product" and Tourism Industry to Promote the Development of the New Rural Economy
}

\author{
Xinping Yuan \\ Wuhan University of Science and Technology \\ Wuhan, China
}

\author{
Hui Lu \\ Wuhan University of Science and Technology \\ Wuhan, China
}

\begin{abstract}
The 19th National Congress of CPC has put the development of "new and beautiful countryside" on agenda. In response to the appeal of the Central Government to build new socialist countryside, all agricultural departments have begun to vigorously carry out the policy of "one village, one product" on the theme of "three rural issues". They combine the fruits of this management mode with the tourism industry, and try to promote the industrialization of "one village, one product". The tourism drives the development of agriculture, as well as the development of rural economy. The combination management mode of "one village, one product" and the tourism industry becomes an important way to deepen the adjustment of agricultural structure and increase income of farmers. However, in practice of this mode, there are a lot of problems, such as, single variety, weak industrial chain and uncompleted residential flats, due to overstressing leading industry and blindly building image projects in tourism. It has greatly affected the promotion and development of this mode. In order to correctly grasp characteristics and development situations in the combined mode of "one village, one product" and tourism industry and thus perfect this mode, the paper has made comparative analysis and in-depth exploration on related problems, with the Qianjiang Zhaonao Village and the Tianmen Tiwuling Village in Hubei Province as example.
\end{abstract}

Keywords-new beautiful countryside; one village, one product; tourism industry chain; economic development

\section{INTRODUCTION}

In the construction of new beautiful countryside, it has been unable to meet the demands of rural development with single leading industry or the development of tourism in order to develop rural industrial economy, and build inner power for rural industry. Therefore, it is particular important to apply the combination production mode of "one village, one product" and tourism industry at present.
II. ANALYSIS OF THE CURRENT SitUATION OF THE Combination of "One Village, One Product" AND the TOURISM INDUSTRY IN THE PROMOTION OF ECONOMIC DEVELOPMENT

A. The Connotation, Characteristics and Advantages of the Combination Mode of "One Village, One Product" and Tourism Industry

"One village, one product" refers to a leading product and industry with a distinct regional characteristics and high added value by taking full advantage of local resources, traditional advantages and regional advantages, and the vigorous promotion of large-scale, branding and marketization construction. The combination mode of "one village, one product" and tourism industry is to develop tourism industry while strengthening production in the leading industry, and to promote the vigorous development of agricultural industry through the advantages of tourism itself and create the great leap forward of rural economy.

"One village, one product" combines with the tourism industry, achieving the complementary advantages, which can play a great role in promoting the development of the rural economy. First of all, "one village, one product" provides the possibility for the development of the tourism industry. Meanwhile, "one village, one product" can become the core competitiveness of the tourism industry in the region. It makes the original single leading industry compound, and strengthens the rural endogenous power. Secondly, the development of tourism can promote the optimization and upgrading of the industrial structure of "one village, one product". Based on the needs and opinions of tourists and the function of market economy, leading industry will be improved and deepened continuously in the original basis. Increase the added value of the products, and explore the new and high technology to meet the needs of the market and customers, and thus increase competitiveness. Finally, the combination of "one village, one product" and tourism industry can coordinate the development of environment and promote the beautification of environment. Relevant departments will strengthen supervision on environmental pollution, which can achieve sustainable development. 


\section{B. Analysis of Successful Cases under the Combination Mode of "One Village, One Product" and Tourism Industry}

1) Analysis of the previous situation: Qianjiang City, located in the Jianghan Plain in the middle of Hubei Province, was a corner of the Yunmeng Lakes in ancient times, which has been gradually formed by the complex alluvium of the river water and the slow deposition of the lake water. Zhaonao Village is located in the southernmost of Xiongkou Town, Qianjiang City. There was ever site of hospital of Xiangnan Army and red revolution area in the revolution period. With 10 villagers groups, 648 households and 2,588 people, the village covers an area of $12,221 \mathrm{mu}$.

Before 2013, most cultivated lands in Zhaonao Village were low-lying fields. The low-lying land with numerous lakes makes it known as "water bag". 1/3 low-lying fields (cold and immersed farmland) each year can only produce one season of rice. In other seasons, the fields are filled with water, and idle. The water conservancy facilities here are backward, and the traffic is very inconvenient.

In 2013, the cultivated area of Zhaonao Village is 6,779 $\mathrm{mu}$, of which 3,857 mu are paddy fields; $2,922 \mathrm{mu}$ are dry land. It mainly plants traditional cotton, wheat, rape and rice. With low yield, the village has no other industry. It was a famous poor village in the town.

In that year, the per capita net income of farmers was 10,228 yuan. The net income of yield from $1 \mathrm{mu}$ field was 1,000 yuan, and the collective economic accumulation of village basically depended on rent of the mobile fields. The collective economy accumulated was 10 thousand yuan annually. As a result, a large number of young villagers flew out and worked in city. The main income of the villagers is wages by working outside.

2) Analysis of the current situation: In July 2013, Xiongkou Town was selected as one of 21 pilot towns in industrialization, informatization, urbanization and agricultural modernization by the provincial government and provincial party committee. Under support of government at all levels, the development mode of "one village, one product" was introduced into Zhaonao Village. It has been focusing on the development of "shrimp and rice", which has produced a standardized shrimp and rice farming base.

Zhaonao Village has carried out the policy of making room by migration, renting land of individual farmers and lending to large agricultural companies". According to the mode of "company + cooperative + base + farmer", the village has strengthened cooperation with Huashan Company. Through the transfer of land, Huashan Company gave village 666 per mu and merged the fields of different size. According the standard of one shrimp pond, $40 \mathrm{mu}$ field, the company built 220 standard shrimp ponds, forming a 10,000$\mathrm{mu}$ industrial base. Huashan Company rent these ponds to the cooperatives (the two cooperatives, "Funong Nongii" and "Lvtu Xiadao Gongzuo", undertaken by the villages led by the party branch of village) in the village with the price of
667 yuan per mu, adding one yuan to the original price. The cooperatives are mainly responsible for breeding ripe shrimps and planting rice. Huashan Company is responsible for the cultivation of quarterly shrimp seed and the acquisition of shrimp and rice. It forms a win-win situation of Huashan Company and villagers. Zhaonao Village has made a success with the mode of "one village, one product". Then many pilot villages merge their industries, which has greatly driven the development of "crayfish" tourism industry in Xiongkou Town.

With the development of "one village, one product" and "shrimp \& rice" industry, and the brand promotion role of "crayfish" tourism industry, as of 2017, it is expected that the annual net income of 1-mu field has increased to around 5,000 yuan. 1-mu field can produce $300 \sim 400$ jin crayfish, and The supply of crayfish is not adequate to demand in food and beverage industry. The ripe crayfish sales at the price of 20 - 40 yuan per jin respectively in harvest period and slack season. Because of the breeding of crayfish, farmers can't use pesticides for growing rice, and thus produce an additional product of "environmental friendly rice". 1-mu field can produce $800 \sim 1,000$ jin rice. After the combination of raising shrimp and planting rice, one household can get over 150,000 yuan every year. By building base and developing crayfish industry, the collective income of the village can reach to 900,000 yuan. Among them, the land income of mobile land and forest land can reach to 300,000 yuan. The income from service and management fee can reach to 500,000 yuan, and the cooperatives can get 100,000 yuan.

\section{Problems IN THE Process that "ONe VIllage ONE PRODUCT" INTEGRATES WITH TOURIST INDUSTRY TO DRIVE ECONOMIC DEVELOPMENT}

\section{A. Misunderstanding in the Development Process with the Integration of "One Village One Product" and Tourist Industry}

Because the economic gain from the combined development of "One Village One Product" and tourist industry is considerable, nowadays many villages compete to adopt the development pattern, including villages that blindly imitate and develop. Some villages fail to obtain a return, and the reasons mainly come from three aspects. Firstly, for the achievements in official career, some leaders at village level or town level don't consider the physical truth. They blindly develop, implement strategies and spend most of the time in face-saving project, causing a large number of unfinished buildings. Secondly, designers or planners in new rural construction don't have enough speaking right in the reconstruction process. They have to meet the requirements of local leaders and fail to give full play to their professional design level, so the finished buildings are unsatisfactory. Besides, most designers neither have enough sociological knowledge nor correctly follow the context of rural economic development. Thirdly, the conformity of individual investors makes "One Village One Product" industry in towns become more identical. The leading industry doesn't have local characteristics and are "brought". Farmers covet affiliated industries that have a sound 
development such as the catering industry. They rush up in a crowd and finally form the situation that "there are a lot of customers in one shop but other shops are left without anybody to care for it".

\section{B. Analysis on Failed Case under the Pattern that "One Village One Product” Combines with Tourist Industry}

1) Background introduction: Located in Huangtan Town in Tianmen City of Hubei Province, Qiwuing Village is a large swampland. Sanjun Chrysanthemum Plantation Specialized Cooperative is one of the cooperatives under the development of tourist industry related to "One Village One Product" in Qiwuling Village. General Manager Zhang of the cooperative is a member of Qiwuing Village and registered the cooperative in October 2015. The existing farmland covers an area of $162 \mathrm{mu}$ and General Manager Zhang spends RMB 800 per mu annually in taking over it from villagers. There are 120 workers in the cooperative, including 25 low income families, most of who are middle aged and elderly people with weak labor force and earn RMB 50 to 80 per day. General workers earn RMB 80 to 120 per day. The pattern of more pay for more work but without clear assignment for the types of work is conducted. The works mainly include chemicals spraying, fertilization, ditching and carrying things, and the public and private centralized system is executed.

2) Analysis on the current situation after industrial development: More than 2,000 kinds of chrysanthemums exist in Sanjun Chrysanthemum Plantation Base with the main profiting means of the appreciation of chrysanthemums and the sale of sprout and flowers. It is the typical development pattern that "One Village One Product" combines with the tourist industry. The Chrysanthemum Cooperative conducts the tourist promotion through the pattern of "scenic area plus popularization of science plus activities". However, the insufficient development of surrounding industries such as hotel industry, catering industry and retail industry restricts the further development of the chrysanthemum industry, which presents a week development.

At the present stage, the Chrysanthemum Cooperative has contributed nearly RMB ten million independently, including RMB 2.8 million to 2.9 million for infrastructure, RMB 6 million to 7 million for production expenses and fees for over 200 greenhouses. However, the Chrysanthemum Cooperative is at a loss because the flood in the middle and lower reaches of Yangtze River occurred on Dec.27, 2015 submerges all the cultivated lands of Qiwuling Village and causes the loss of nearly RMB 9 million of the Chrysanthemum Cooperative.

The primary income of villagers of Quwuling Village comes from young people who work outside. At present, the majority of people in the village are middle-aged women, leftover children and empty-nest elderly. Restricted by funds and resources, the Chrysanthemum Cooperative cannot absorb more labors. At the meantime, the development of the cooperative is also restricted.

\section{Contrastive Analysis on Cases that Use the Pattern of Combing "One Village One Product" with Tourist Industry}

1) Analysis on reasons for the success of "Lobster Rice" industry: Zhaonao Village depends on the pattern of "government plus company plus cooperative plus base plus farmers plus individual". The government is responsible for brand promotion and the company supplies lobster larvae and purchases mature lobster and rice and provides one package service. The cooperative gathers farmers to meet the requirement for labor force and crate the characteristic "Lobster Rice" industrial base. Self-employed businessmen develop surrounding industries through market economy such as catering, tourism, construction, retailing, wholesale, e-commerce and logistics. Six-in-one forms the complete industrial chain to make the production become large scale and sustainable. As the leading enterprise of "Lobster Rice" industry, Huashan Company cooperates with the cooperative to enter the market. The leading enterprise guarantees the lobster larvae, fertilizer and sale of the cooperative and reduces most of the market risk for the development of the cooperative.

Meanwhile, under the circumstance that the economic development is sustainable and stable, the company invites researchers in universities to further develop the lobster industry and seek breakthrough point in high-tech fields such as the breeding of lobster larvae and the extraction of astaxanthin, in order to deepen the industrial structure. The industrial development of "One Village One Product" drives "One Town One Product" and "One City One Product", in order to make the "Lobster Rice" industry have advantaged market competitiveness.

Nowadays, as the famous brand in catering and tourist industries, "Qianjiang Lobster" created by the government greatly increases the requirement for lobster even causes the situation that demand exceeds supply. It has promoted the flourishing development of "Lobster Rice" industry. The situation that "Lobster Rice" industry and tourist industry influence and promote each other has formed. They give full play to the advantage of this pattern in rural economic development.

2) Analysis on the reasons for the failure of "chrysanthemum" industry in Qiwuling Village: The industrial structure of the Chrysanthemum Cooperative in Quwuling Village is simple. Nowadays, it only realizes the production pattern of "cooperative plus farmers". The Cooperative is responsible for land transfer, the plantation and sale of chrysanthemum and reception of tourists, and farmers only provide labor force. The absence of some industrial chain restricts the development of the Cooperative, which has no advantage in sale an attracting tourists and hardly expand the scale of production. Furthermore, the Chrysanthemum Cooperative does not cooperate with any 
leading enterprise or company. When entering the market, the single cooperative has insufficient funds and resources without the protection of leading enterprises. The immeasurable market risk will make it difficult for them to survive in the market competition.

Four cooperatives exist in Qiwuling Village and have different industries, which have no relationship with each other and don't cooperate with each other. Scattering in the village, just like the Chrysanthemum Cooperative, they don't have the complete structure of industrial chains. The cooperatives conduct the production of tourist industry but fail to cooperate with villagers in Qiwuling Village to develop surrounding industries of related supporting facilities, so no basic hardware facilities such as catering and accommodation exist. The single cooperative develops independently without inadequate market vitality and has limited reception capacity. Meanwhile, the inadequate attraction and propaganda work make the tourist flow volume reduce year by year. At the same time, the survival rate of cooperatives will reduce.

\section{SUGGESTIONS ON DRIVING ECONOMIC DEVELOPMENT THROUGH THE INTEGRATION OF "ONE VILLAGE ONE PRODUCT” WITH TOURIST INDUSTRY}

\section{A. Deepen the Structure of Industrial Chains}

The production pattern that integrates "One Village One Product" with tourist industry should be developed. Firstly, the village should have industries with local characteristics and adjust measures to local conditions such as develop "lobster rice" industry in bottomland, in order to make products have distinctive features and high recognition. Secondly, cooperatives should cooperate with leading enterprises to obtain abundant financial resources for industries. They must avoid fighting alone to lower the risk. Thirdly, they should give full play to the role of selfemployed businessmen and villages and drive market vitality. Policy support combines with market regulation. The improvement of surrounding industries of the leading industry and related supporting facilities is encouraged, such as catering, recommendation and traffic. The basic reception ability of tourist industry as the leading industry must be guaranteed. Lastly, they must increase the additional value of leading industry, actively develop derivative products and prolong the structure of industrial chains as well as deepen the industrial development. Meanwhile, it's also necessary to increase the input in researching high and new technology and strengthen the originality and market competitiveness of products.

\section{B. Publicity and Cooperation}

The intensification of publicity through government to create brand effect is of vital importance for developing the production pattern that integrates "One Village One Product" with tourist industry. It can create the atmosphere of tourism and attract more tourists to promote industrial development.

At the meantime, village cadres also should strengthen the publicity and communication of self-employed businessmen and villagers and let them eliminate the crowd mentality, give counsel for the development of leading industry and its surrounding industries and strengthen market vitality. The masses take the initiative to participate in the development of industry to promote the common economic development.

Designers and planers of new rural construction are encouraged to apply professional knowledge and contribute to the development and popularization of the production pattern that combines "One Village One Product" with tourist industry. Through enough communication and description, they patiently explain key points and intentions in the design schemes to the masses and strive to become the balance point of contradictions between leaders and the masses. Meanwhile, they should avoid the situation that individual opinions of local leaders and villagers determine the overall development and realize the sound renovation design of the beautiful new countryside.

\section{CONCLUSION}

Under the construction of beautiful new countryside, the production pattern that integrates "One Village One Product" with tourist industry requires us to grasp the characteristic leading industry at the same time stimulate market vitality, improve the structure of industrial chains and give full play to the advantages of tourist industry. We must learn the sixin-one strategic guideline of Zhaonao Village, create the characteristic "Lobster Rice" industry and deepen the industrial chains to form a strong competitiveness. Meanwhile, we have to reflect current situation of Qiwuling Village, including the independent development of cooperatives, the break of industrial chains, the absence of villagers' support and industries lacking market vitality, which make it difficult for the village to expand and develop.

\section{REFERENCES}

[1] Lyu Fan, Tu Bingkun. Analysis on the Mode of Production and Management "Company plus Base plus Farmers" [J], Hubei Agricultural Sciences, 2011, the 21st Edition

[2] Zhang Yuan, Wang Yigui. Research on the Current Situation of "One Village One Product" and Development Countermeasures: Instance Jiangyan District, Taizhou City of Jiangsu Province [J], China Agriculture Information, 2013, the 12th Edition

[3] Duan Xiuping, Yu Deyun. Discussion on Developing the Economy of "One Village One Product" [J], Economic Review, 2007, the 3rd Edition

[4] Liu Ping. Creative Agriculture in Japan and New Rural Construction [J], Contemporary Economy of Japan, 2009, the 3rd Edition

[5] Wang Gaoyong. Grasp Five Aspects, Solidly Work and Promote the Development of "One Village One Product", "One County One Industry" [J], China Agricultural Information, 2011, the 9th Edition. 